\title{
Scorpions (Arachnida, Scorpiones) from the state of Acre, southwestern Brazilian Amazon
}

\author{
André Felipe de Araujo LIRA ${ }^{1 *}{ }^{\mathbb{C}}$, Edson GUILHERME², Moisés Barbosa de SOUZA², Leonardo Sousa \\ CARVALHO $^{3}$

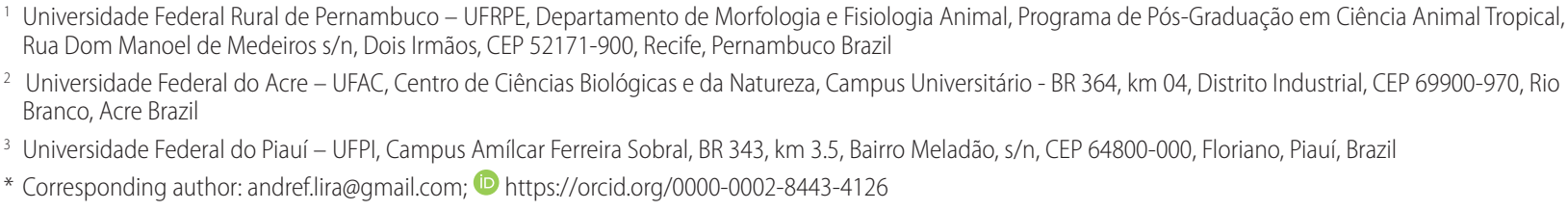

\section{ABSTRACT}

Although Brazil has one of the highest scorpion diversities worldwide, the scorpion fauna of the Amazon region remains relatively poorly described. In this study, we updated the list of scorpion species from the state of Acre, in the southwestern Brazilian Amazon, based on a revision of records contained in Brazilian arachnid collections and a survey of the relevant literature. We recorded the occurrence of seven scorpion species belonging to two families (Buthidae and Chactidae) among which we report three new records (Ananteris sp., Tityus (Tityus) gasci, and Chactopsis cf. insignis) for Acre. The results presented herein make an important contribution to the knowledge on scorpion diversity in the Amazonian forests of Acre.

KEYWORDS: Buthidae, Chactidae, checklist, new record, Wallacean shortfall

\section{Escorpiones (Aracnida, Scorpiones) del estado de Acre, suroeste de la Amazonía brasileña}

\section{RESUMEN}

Aunque Brasil tiene una de las diversidades de escorpiones más altas del mundo, la fauna de escorpiones de la región amazónica sigue siendo relativamente poco descrita. En este estudio, actualizamos la lista de especies de escorpiones para el estado de Acre, en el suroeste de la Amazonía brasileńa, en base a una revisión de los registros contenidos en colecciones de arácnidos brasileños y un estudio de la literatura relevante. Registramos la ocurrencia de siete especies de escorpiones pertenecientes a dos familias (Buthidae y Chactidae), entre las cuales informamos tres nuevos registros (Ananteris sp., Tityus (Tityus) gasci y Chactopsis cf. insignis) para Acre. Los resultados presentados aquí hacen una contribución importante al conocimiento acerca de la diversidad de escorpiones en los bosques amazónicos de Acre.

PALABRAS-ClaVE: Buthidae, Chactidae, lista de especies, nuevos registros, déficit de Wallace

The order Scorpiones constitutes a group of invertebrates that have successfully colonized a variety of environments. Worldwide, there are approximately 2,470 known species of scorpions, which, with the exception of Antarctica, are distributed across all continents (Polis 1990; Rein 2019). The Brazilian scorpion fauna comprises approximately 160 known species distributed among four families (Lourenço 2002; Coelho et al. 2016), of which the highest diversity ( $>50 \%$ of the species richness) is found in the Northern region, which covers $45 \%$ of the country and is mostly covered by Amazon forest (IBGE 2016; Brazil and Porto 2011). The scorpion fauna of the Brazilian Amazon is highly diverse, with representatives of all four scorpion families recorded in Brazil, namely, Buthidae C.L. Koch, 1837; Bothriuridae Simon, 1880; Chactidae Pocock, 1893; and Hormuridae Laurie, 1896 (Lourenço 2002). However, numerous species are known from just a single locality (e.g., Lourenço 2005; Lourenço and Qi 2007) or have been described based exclusively on juvenile specimens (e.g., Lourenço et al. 2005a; Lourenço and Silva 2007), whereas for others certain important taxonomic characters (such as hemispermatophore morphology) have not been described (e.g., Lourenço 2005; Lourenço and Qi 2007), thereby making species identification and recognition more difficult. At state level, the highest scorpion diversities in Brazil are reported for the Amazonian states of Amazonas (approximately 40 species) and Pará (approximately 20). In 
Acre state, in the southwestern Brazilian Amazon, only four species have been reported (Lourenço 2002; Brazil and Porto 2011). Here, we present an updated species list for Acre, based on a revision of collection material accumulated over the past three decades and a literature review.

The state of Acre, covers an area of $164,221.36 \mathrm{~km}^{2}$ and borders with Peru, Bolivia and the Brazilian states of Amazonas and Rondônia (Acre 2006; Figure 1). Compared with other Brazilian states, Acre has a relatively high number of plant, vertebrate, and invertebrate species (Oliveira et al. 2016). Between 1984 and 2015, students and staff from Universidade Federal do Acre (UFAC), and other members of the community, collected scorpions throughout the state (Table 1). The collected material was identified by means of relevant literature (Lourenço 2002; Lourenço et al. 2005b; Ochoa et al. 2013). All the specimens were deposited in the Arachnological Collection of Universidade Federal de Pernambuco (UFPE; curator L. Ianuzzi). We also had access to additional material from the zoological collection (Laboratório
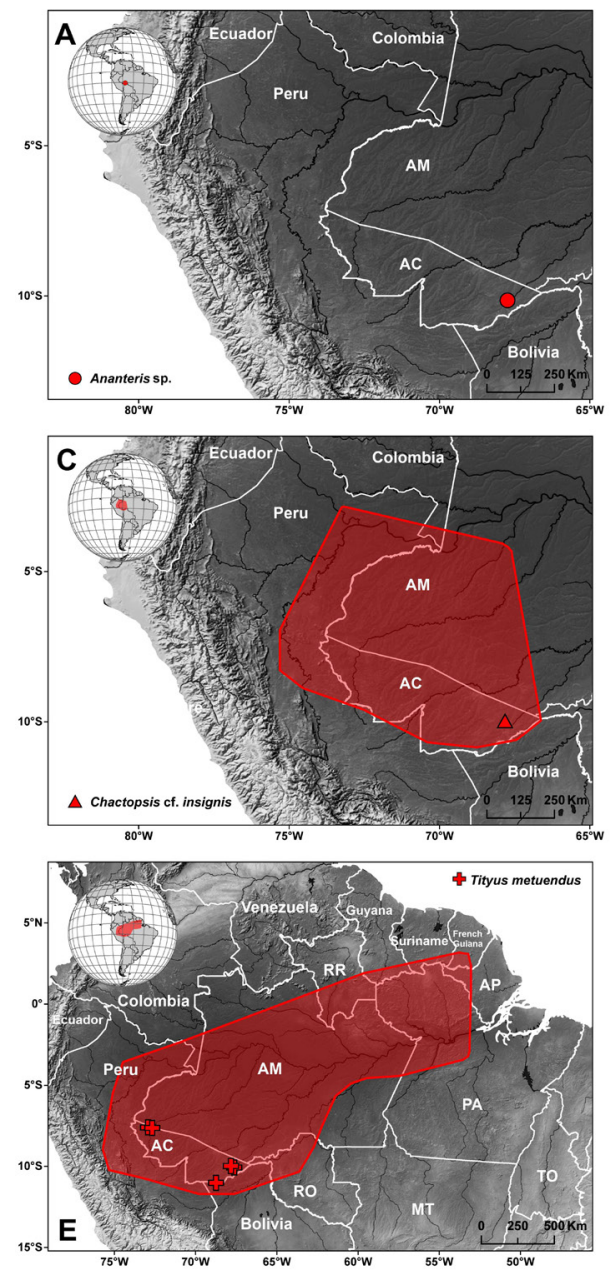

Especial de Coleçóes Zoológicas) at Instituto Butantan (IBSP; curator A.D. Brescovit). We also consulted the database of the zoological collections of Centro de Coleçóes Taxonômicas at Universidade Federal de Minas Gerais (UFMG; curator A.J. Santos) and Instituto Nacional de Pesquisas da Amazônia (INPA; curator M.L. Oliveira), accessed through Species Link (CRIA 2020). We found the latter two databases to contain records for Acre of Tityus (Atreus) obscurus Gervais, 1843 and Chactas brevicaudatus (Karsch, 1879), both of which we suspect to be misidentifications, given that $T$. (A.) obscurus is known only from the eastern Amazon (Lourenço et al. 2000), whereas C. brevicaudatus is endemic from Colombia (Lourenço 1991). Accordingly, these two species were excluded from the species list.

A total of 31 scorpion specimens belonging to seven species have been recorded in Acre, (Table 1; Figure 2). The scorpions were collected from sites in eight municipalities, with the largest number of species being recorded in Rio Branco ( 4 species), Senador Guiomard (4), and Mâncio Lima (3) (Table
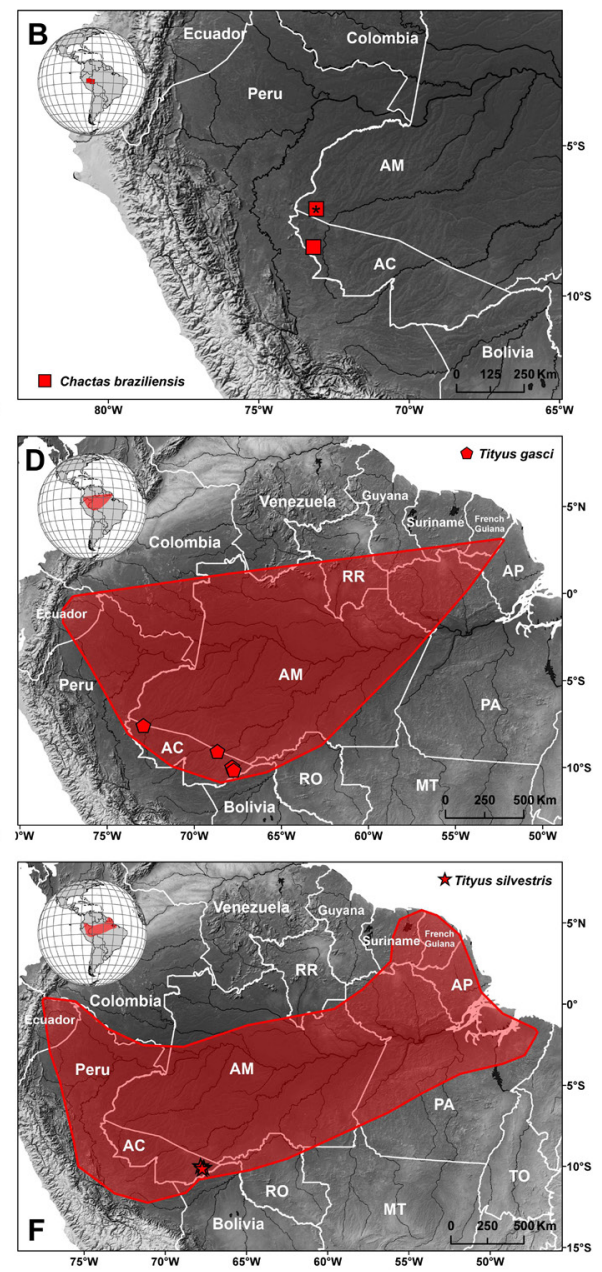

Figure 1. Overall distribution and collection localities in the state of Acre of the six native scorpion species recorded for Acre, southwestern Brazilian Amazon. Distribution data were obtained from literature. This figure is in color in the electronic version. 


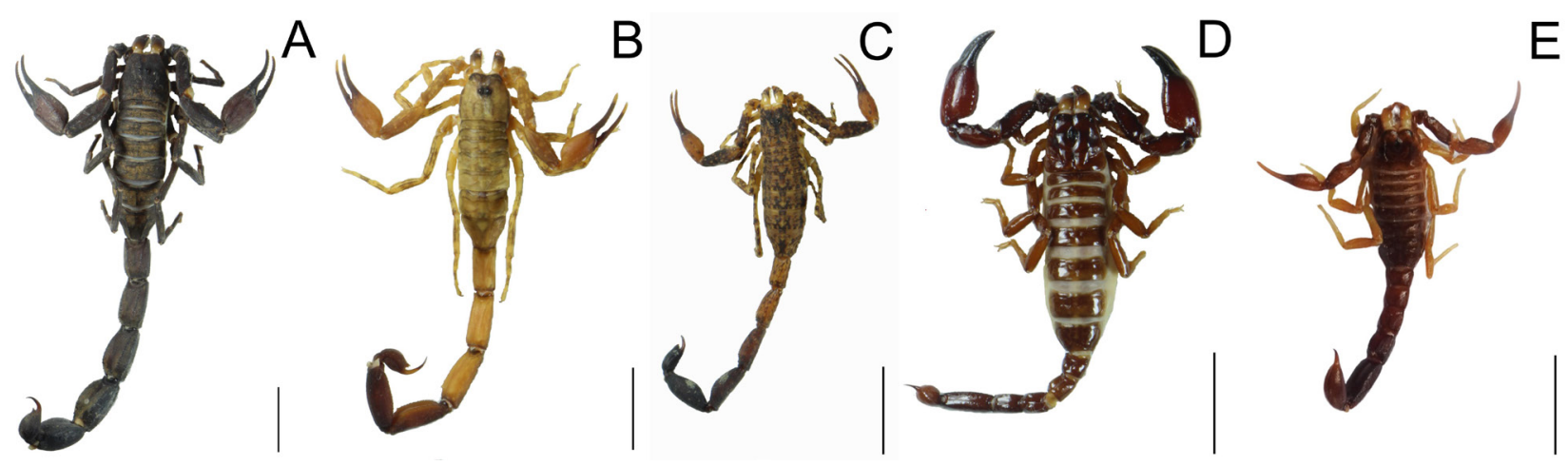

Figure 2. Representative specimens of five of the seven scorpion species recorded in the state of Acre, in the southwestern Brazilian Amazon. A - Tityus (Atreus) metuendus (CA-UFPE 1588); B - Tityus (Tityus) gasci (CA-UFPE 1492); C - Tityus (Archaeotityus) silvestris (CA-UFPE 1495); D - Chactas braziliensis (CA-UFPE 1583); E Chactas cf. insignis (CA-UFPE 1602). Credit: João Regueira (A-D) and Edson Guilherme (E). Scale bar $=1 \mathrm{~cm}$. This figure is in color in the electronic version.

Table 1. Scorpion species recorded in the state of Acre, southwestern Brazilian Amazon. *New record.

\begin{tabular}{|c|c|c|}
\hline Family/Species & Locality & Collection voucher \\
\hline \multicolumn{3}{|l|}{ Buthidae } \\
\hline *Ananteris sp. & Senador Guiomard & IBSP-SC 4791 \\
\hline Isometrus maculatus (DeGeer, 1778) & Acre & IBSP-SC 5573 \\
\hline Tityus (Archaeotityus) silvestris Pocock, 1897 & $\begin{array}{l}\text { Rio Branco } \\
\text { Senador Guiomard }\end{array}$ & $\begin{array}{c}\text { CA-UFPE } 1495,1496,1581,1584 ; \text { I IBSP-SC } 4798 \\
\text { CA-UFPE 1494; UFMG } 10173\end{array}$ \\
\hline *Tityus (Tityus) gasci Lourenço, 1981 & $\begin{array}{l}\text { Mâncio Lima } \\
\text { Rio Branco } \\
\text { Sena Madureira } \\
\text { Senador Guiomard }\end{array}$ & $\begin{array}{c}\text { CA-UFPE } 1493 \\
\text { CA-UFPE 1499, 1585, 1586; IBSP-SC } 5127 \\
\text { CA-UFPE } 1582 \\
\text { CA-UFPE } 1492\end{array}$ \\
\hline Tityus (Atreus) metuendus Pocock, 1897 & $\begin{array}{l}\text { Brasiléia } \\
\text { Cruzeiro do Sul } \\
\text { Mâncio Lima } \\
\text { Rio Branco } \\
\text { Senador Guiomard } \\
\text { Xapuri }\end{array}$ & $\begin{array}{c}\text { CA-UFPE } 1500 \\
\text { CA-UFPE 1600; IBSP-SC } 3586 \\
\text { CA-UFPE 1587, } 1601 \\
\text { CA-UFPE 1588, 1589; IBSP-SC 3586, } 5125 \\
\text { UFMG 6565; } 11364 \\
\text { CA-UFPE } 1501\end{array}$ \\
\hline \multicolumn{3}{|l|}{ Chactidae } \\
\hline Chactas braziliensis Lourenço, Aguiar \& Franklin, 2005 & Mâncio Lima & CA-UFPE 1542, 1583 \\
\hline *Chactopsis cf. insignis Kraepelin, 1912 & Rio Branco & CA-UFPE 1602 \\
\hline
\end{tabular}

1). Tityus (Atreus) metuendus and T. (T.) gasci were widespread species, being recorded in six and four localities, respectively. Of the remaining species, $T$. (A.) silvestris was represented by only two records, whereas all other species were recorded from just a single locality (Table 1).

We provide the first checklist of scorpions for Acre, and seven species have now been documented in the region. In Brazil, this species richness is surpassed only by the states of Amazonas and Pará, which are much larger in area (Figure 1) and have a comparatively longer history of taxonomic studies (e.g., Lourenço et al. 2005a; Pinto-da-Rocha et al. 2007; Lourenço and Duhem 2010). Although the records from Acre are far from complete, they are of particular importance, as they significantly reduce the large Wallacean shortfall in theBrazilian scorpion fauna. The scorpions recorded from Acre belong to either Buthidae (80\%) or Chactidae (20\%), the two most diverse scorpion families in the Brazilian Amazon (Lourenço 2002). The buthid T. (A.) metuendus is a widespread rainforest species that is mainly distributed in the western Amazon (Lourenço 2002; Acosta and Ochoa 2002), where it is responsible for most scorpion-related accidents (Pucca $e t$ al. 2015). Other widespread species are T. (T.) gasci, which is found in French Guiana, Peru, Ecuador, Bolivia and Brazil (Lourenço 2002; Acosta and Ochoa 2002; Brito and Borges 2015), and T. (A.) silvestris, which is also a source of severe accidents in the Brazilian Amazon (Coelho et al. 2016). The latter species inhabits rainforests, where it is found under litter or on palm trees (Lourenço 2002; Brazil and Porto 2011). In addition to its wide distribution, $T$. (A.) silvestris is also characterized by a considerably high level of polymorphism (Lourenço 1988). This combination of factors could indicate the existence of cryptic species, as evidenced by a thorough revision of the subgenus Archaeotityus (Lourenço et al. 2006; Lourenço 2012) as it has previously been demonstrated for Colombian species (Moreno-González et al. 2019). The other four species were represented by single records. To date, nine Ananteris species have been reported from the Brazilian Amazon (Lourenço et al. 2013), and our findings confirm the occurrence of this genus in Acre. However, more specimens are required to make an identification at species level, given that 
the only individual examined was a juvenile, and therefore, difficult to identify. Isometrus maculatus is an exotic species, introduced from the Indo-Malayan region to several tropical regions of the world, possibly being transported in ships (Kovařík 2003). The species was recorded in Acre in 1955 (Piza 1955), however, the specimen reported herein was recorded seven years prior to that reported in Acre by Piza (1955). This suggests that a breeding population exists in the state, or that multiple invasions have occurred in the region.

Finally, we also documented the chactid Chactopsis cf. insignis, which has previously been reported only from the state of Amazonas and from several localities in Peru. Our record therefore fills a gap in the distribution range of this species (Ochoa et al. 2013). The identification of this species was based on a female specimen (CA-UFPE \#1602). Ideally, a male is required to confirm the species identity, based on hemispermatophore morphology (see Ochoa et al. 2013). We also confirmed the presence of the chactid Chactas braziliensis in Acre, a male specimen which was recently described (Lira et al.2018). Our results contribute to increase the knowledge on the diversity of scorpions in the Amazonian forest and can serve as a reference for future studies.

\section{ACKNOWLEDGMENTS}

We are grateful to Fundação de Amparo à Ciência e Tecnologia do Estado de Pernambuco (FACEPE) for a postdoctoral scholarship (BFP-0010-2.05/19) to AFAL. We are also grateful to Dr. Antônio D. Brescovit and Dr. Adalberto J. Santos for providing scorpion records from the Butantan Institute and Universidade Federal de Minas Gerais arachnological collections, respectively.

\section{REFERENCES}

Acosta, L.E.; Ochoa, J.A. 2002. Lista de los escorpiones bolivianos (Chelicerata: Scorpiones), con notas sobre su distribución. Revista de la Sociedad Entomológica Argentina, 61: 15-23.

Acre. 2006. Governo do Estado do Acre. Programa Estadual de Zoneamento Ecológico Econômico Fase II: documento Sintese Escala 1:250.000. SEMA, Rio Branco. 356p.

Brazil, T.K.; Porto, T.J. 2011. Os Escorpiōes. EDUFBA, Salvador, 84p.

Brito, G.; Borges, A. 2015. A checklist of the scorpions of Ecuador (Arachnida: Scorpiones), with notes on the distribution and medical significance of some species. Journal of Venomous Animals and Toxins including Tropical Diseases, 21: \# 23. doi: 10.1186/ s40409-015-0023-x

Coelho, J.S.; Ishikawa, E.A.Y.; Dos Santos, P.R.S.G.; Pardal, P.P.O. 2016. Scorpionism by Tityus silvestris in eastern Brazilian Amazon. Journal of Venomous Animals and Toxins including Tropical Diseases, 22: \#24. doi: 10.1186/s40409-016-0079-2

CRIA. 2020. SpeciesLink (http://splink.cria.org.br/ project?criaLANG=pt). Accessed on 20 Jun 2020.

IBGE. 2016. Instituto Brasileiro de Geografia e Estatística (http:// www.ibge.gov.br/home). Accessed on 05 Dec 2016.
Kovařík, F. 2003. A review of the genus Isometrus Ehrenberg, 1828 (Scorpiones: Buthidae) with descriptions of four new species from Asia and Australia. Euscorpius, 10: 1-19.

Kovařík, F.; Teruel, R.; Lowe, G.; Friedrich, S. 2015. Four new scorpion species (Scorpiones: Buthidae) from Amazonian Peru. Euscorpius, 210: 1-40.

Lira, A.F.A.; Pordeus, L.M.; Souza, M.B.; Guilherme, E. 2018. Description of the male of Chactas braziliensis Lourenço, Aguiar \& Franklin 2005 (Scorpiones: Chactidae). Acta Arachnologica, 67: $1-5$.

Lourenço, W.R. 1981. Tityus gasci, nouvelle espéce de scorpion Buthidae de Guyane française. Bulletin du Muséum National d'Histoire Naturelle, 4: 841-845.

Lourenço, W.R. 1988. Diversite biologique et modalites de Ia speciation chez Ies Scorpions amazoniens; Tityus silvestris Pocock, un cas particulier de polymorphisme. Comptes Rendus Biologies, 306: 463-466.

Lourenço, W.R. 1991. Les scorpions (Chelicerata) de Colombie. II. Les faunes des régions de Santa Marta et de la Cordillère Orientale. Approche biogéographique. Senckenbergiana Biologica, 7: 275-288.

Lourenço, W.R. 1992. Biogéographie des espèces du groupe naturel Tityus clathratus (Chelicerata, Scorpiones, Buthidae). Bulletin du Muséum National d'Histoire Naturelle, 14: 473-481.

Lourenço, W.R. 2002. Scorpions of Brazil. Les Édition de I'lf, Paris, $308 \mathrm{p}$.

Lourenço, W.R. 2005. Humicolous buthoid scorpions: a new species from Brazilian Amazon. Comptes Rendus Biologies, 328: 949-954.

Lourenço, W.R. 2012. Further considerations on Tityus (Archaeotityus) clathratus CL Koch, 1844 and description of two associated new species (Scorpiones: Buthidae). Boletín de la Sociedad Entomológica Aragonesa, 50: 277-283.

Lourenço, W.R.; Adis, J.; Araújo, J.S. 2005a. A new synopsis of the scorpion fauna of the Manaus region in Brazilian Amazonia, with special reference to an inundation forest at the Tarumã Mirim river. Amazoniana, 18: 241-249.

Lourenço, W.R.; Aguiar, N.O.; Franklin, E. 2005b. First record of the scorpion genus Chactas Gervais, 1844, for Brazil with description of a new species from western state of Amazonas (Scorpiones: Chactidae). Zootaxa, 984: 1-8.

Lourenço, W.R.; Duhem, B. 2010. The geographical pattern of distribution of the genus Teuthraustes Simon (Scorpiones, Chactidae) in South America and description of a new species. Comptes Rendus Biologies, 333: 858-863.

Lourenço, W.R.; Giupponi, A.P.; Leguin, E.A. 2013. Description of three more new species of the genus Ananteris. Anais da Academia Brasileira de Ciências, 85: 709-725.

Lourenço, W.R.; Huber, D.; Cloudsley-Thompson, J.L. 2000. Notes on the ecology, distribution and postembryonic development of Tityus cambridgei Pocock, 1897 (Scorpiones, Buthidae) from French Guyana and Oriental Amazonia. Entomologische Mitteilungen aus dem Zoologischen Museum Hamburg, 13: 197203.

Lourenço, W.R.; Jesus-Junior, M.M.B.G.; Limeira-de-Oliveira, F. 2006. A new species of Tityus CL Koch, 1836 (Scorpiones, 
Buthidae) from the state of Maranhão in Brazil. Boletín Sociedad Entomológica Aragonesa, 38: 117-120.

Lourenço, W.R.; Qi, J.X. 2007. Additions à la faune des scorpions de l'Etat du Amapá, Brésil (Chelicerata, Scorpiones). Revue Suisse de Zoologie, 114: 3-12.

Lourenço, W.R.; Silva, E.A. 2007. New evidence for a disrupted distribution pattern of the Tityus confluens complex, with the description of a new species from the state of Pará, Brazil (Scorpiones, Buthidae). Amazoniana, 19: 77-86.

Moreno-González, J.A.; González, R.O.; Eduardo Flórez, E.D. 2019. Taxonomic revision of the Colombian Tityus (Archaeotityus) (Scorpiones, Buthidae) species: a morphological and morphometric approach, with a description of a new species. Zootaxa, 4660: 1-94.

Ochoa, J.A.; Rojas-Runjaic, F.J.; Pinto-da-Rocha, R.; Prendini, L. 2013. Systematic revision of the Neotropical scorpion genus Chactopsis Kraepelin, 1912 (Chactoidea: Chactidae), with descriptions of two new genera and four new species. Bulletin of the American Museum of Natural History, 378: 1-121.

Oliveira, U.; Paglia, A.P.; Brescovit, A.D.; Carvalho, C.J.B.; Silva, D.P.; Rezende, D.T.; et al. 2016. The strong influence of collection bias on biodiversity knowledge shortfalls of
Brazilian terrestrial biodiversity. Diversity and Distributions, 22: 1232-1244.

Pinto-da-Rocha, R.; Barreiros, J.A.; Araújo, C.; Bonaldo, A. 2007. Arthropoda, Arachnida, Scorpiones: Estação Científica Ferreira Penna and Juruti Plateau, Pará, Brazil. Check List, 3: 145-148.

Piza, S.T. 1955. Notable geographical expansion of a peculiar type of chromosomal constitution of the cosmopolitan scorpion Isometrus maculatus. Arquivos do Museu Nacional, 42: 611-612.

Polis, G.A. 1990. The Biology of Scorpions. Stanford University Press, Stanford, 587p.

Pucca, M.B.; Oliveira, F.N.; Schwartz, E.F.; Arantes, E.C.; Lira-daSilva, R.M. 2014. Scorpionism and dangerous species of Brazil. In: Gopalakrishnakone, P.; Possani, L.D.; Schwartz, E.F.; De La Vega, R.R. (Ed.). Scorpion Venoms. Springer Netherlands, Dodrecht, p.299-324.

Rein, J.O. 2019. The Scorpion Files. http://www.ntnu.no/ub/ scorpionfiles/. Accessed on 07 Nov 2019.

RECEIVED: $25 / 04 / 2020$

ACCEPTED: $12 / 10 / 2020$

ASSOCIATE EDITOR: Ana Lúcia M. Tourinho 